\title{
HUBUNGAN PERASAAN KESEPIAN DENGAN PERILAKU BERISIKO TERTULAR HIV/AIDS PADA TENAGA KERJA INDONESIA (TKI) DI KABUPATEN LOMBOK TIMUR
}

\author{
I Made Eka Santosa* \\ *Dosen Prodi S-1 Keperawatan STIKES Mataram \\ Email ;
}

\begin{abstract}
ABSTRAK
Salah satu kelompok populasi yang rawan terhadap penularan HIV/AIDS di Kabupaten Lombok Timur adalah para Tenaga Kerja Indonesia (TKI) mengingat Kabupaten Lombok Timur adalah pengirim TKI terbesar kedua di Indonesia. Mobilitas dan migrasi pada TKI dapat menciptakan kondisi rentan tertular HIV yang didukung oleh perilaku berisiko tinggi untuk tertular HIV/AIDS.

Penularan HIV pada TKI sangat mungkin diakibatkan karena perilaku berisiko tinggi terhadap penularan HIV/AIDS. Selain diakibatkan oleh rendahnya pengetahuan dan sikap terhadap penularan HIV/AIDS, beberapa faktor yang menyebabkan lebih tingginya risiko pada pekerja migran antara lain : mobilitas tinggi, perpisahan dengan pasangan yang menimbulkan perasaan kesepian, terjerumus dalam industri seks, kesulitan beradaptasi dengan kondisi tempat tujuan sehingga rawan stres dan terjebak dalam penggunaan narkoba. Dari beberapa faktor diatas peneliti ingin mengetahui hubungan antara perasaan kesepian dengan perilaku berisiko tertular HIV/AIDS pada TKI di Kabupaten Lombok Timur.

Penelitian ini merupakan penelitian kuantitatif dengan pendekatan crossectional analytic, tehnik sampling yang digunakan adalah purposive sampling dengan jumlah sampel sebanyak 461 orang. Instrument yang digunakan dalam penelitian ini merupakan kuesioner dan pedoman wawancara yang dimodifikasi dari Survey Surveilans Perilaku (SSP) tahun 2005 dan UCLA Loneliness Scale.

Dari hasil pengolahan data statistik didapatkan nilai korelasi Chi-Squared sebesar 0,013 yang berarti lebih kecil dari nilai Alfa 0,05. Dengan demikian dapat disimpulkan ada hubungan antara kesepian dengan perilaku berisiko tertular HIV/AIDS pada TKI di Kabupaten Lombok Timur. Hubungan bersifat positif yang berarti semakin tinggi tingkat perasaan kesepian, semakin tinggi pula perilaku berisiko tertular HIV/AIDS pada TKI di Kabupaten Lombok Timur.
\end{abstract}

Kata kunci : TKI, perasaan kesepian, perilaku berisiko HIV/AIDS.

\section{PENDAHULUAN}

Human Immunodefficiency Virus (HIV) merupakan virus penyebab Acquired Immuno Deficiency Syndrome (AIDS) yang dapat menyerang siapa saja tanpa memandang jenis kelamin, pekerjaan, suku bangsa, agama, status ekonomi maupun status sosial. Namun terdapat kelompok-kelompok berisiko tinggi tertular HIV/AIDS.

Salah satu kelompok populasi yang rawan terhadap penularan HIV/AIDS di Propinsi NTB adalah para Tenaga Kerja Indonesia (TKI) mengingat Propinsi NTB adalah penyumbang TKI terbesar ke-4 di Indonesia. Di Propinsi NTB, para 
eks Tenaga Kerja Indonesia (TKI) baik laki-laki maupun perempuan atau Tenaga Kerja Wanita (TKW) yang terindikasi mengidap HIV/AIDS sudah tergolong banyak yakni 33 orang, terdiri dari 23 orang pengidap HIV dan 10 orang pengidap AIDS. Data itu belum termasuk pengidap HIV/AIDS di kalangan eks TKI yang belum memeriksakan diri di berbagai klinik VCT (Voluntary Counselling and Testing) yang disediakan di sejumlah rumah sakit di Pulau Lombok dan Sumbawa (KPANTB, 2011). Penularan HIV/AIDS pada TKI ini patut diduga diakibatkan oleh perilaku berisiko tinggi tertular HIV/AIDS selama bekerja sebagai pekerja migran di negara tujuan masing-masing.

Penularan HIV pada pekerja migran yang dalam hal ini adalah para TKI sangat mungkin diakibatkan karena perilaku berisiko tinggi terhadap penularan HIV/AIDS. Menurut Hugo (2001), selain diakibatkan oleh rendahnya pengetahuan dan sikap terhadap penularan HIV/AIDS, beberapa faktor yang menyebabkan lebih tingginya risiko pada pekerja migran antara lain : mobilitas tinggi, perpisahan dengan pasangan yang menimbulkan perasaan kesepian, terjerumus dalam industri seks, kesulitan beradaptasi dengan kondisi tempat tujuan sehingga rawan stres dan terjebak dalam penggunaan narkoba, migran menganggap dirinya terbebas dari nilainilai daerah asal dan merasa sebagai anonim sehingga bebas berperilaku risiko tinggi (Hugo, 2001b).

Dengan jumlah TKI dari Kabupaten Lombok Timur yang cukup besar tersebut tentu saja risiko penularan HIV/AIDS pada TKI tersebut harus diwaspadai. Menurut data dari KPAD NTB, jumlah penderita HIV/AIDS di Kabupaten Lombok Timur menempati urutan kedua secara propinsi (dibawah Kota Mataram) dengan 91 orang penderita (KPA-NTB, 2011). Bukan tidak mungkin diantaranya adalah para TKI yang telah kembali ke daerah asalnya yang kemudian dapat menularkan HIV kepada pasangan seksualnya masing-masing jika melakukan hubungan seksual berisiko atau tindakan-tindakan berisiko lainnya.

Pekerja migran adalah penduduk usia produktif yang rentan tertular HIV. Mereka tergolong berisiko tinggi akibat sejumlah faktor, seperti mobilitas yang tinggi, hidup di lingkungan baru, serta jauh dari pasangan. Ini sangat terkait dengan pola migrasi yang merupakan pilihan dengan tingkat kerentanan tinggi, apalagi alur migrasi didominasi pekerja berketerampilan rendah (3 D : dirty, dangerous, difficult) yang merupakan pekerjaan yang ditinggalkan dan tidak diinginkan oleh penduduk asli negara tujuan (Wulan, 2007)

Migrasi memainkan peranan penting dalam penyebaran epidemi HIV/AIDS di seluruh dunia. Migran rentan tertular HIV karena berbagai alasan antara lain berpisah dengan pasangan dan keluarga, norma teman sebaya, penggunaan alkohol, persepsi yang rendah terhadap penularan HIV, keterbatasan akses pada pelayanan kesehatan, dan pendidikan yang rendah. Di China, pekerja migran usia muda lebih awal melakukan hubungan seksual dan memiliki lebih dari satu pasangan seksual, serta lebih sering melakukan hubungan seksual (Ford, 2007). SmithEstelle \& Gruskin (2003) dalam Ford \& Chamrathrithirong (2007) menyatakan bahwa ada beberapa faktor yang mempengaruhi pekerja migran Nepal dalam perilaku seksual berisiko yang meliputi norma dan tekanan teman sebaya, harga pekerja seks yang murah, kurangnya pengawasan keluarga, 
penggunaan alkohol, dan rendahnya pengetahuan dan persepsi tentang penularan HIV (Ford, 2007)

Pada Survey Surveilans Perilaku Berisiko Tertular HIV/AIDS di Aceh tahun 2008 ditemukan bahwa tingkat pengetahuan pencegahan HIV pada pria pekerja migran sangat rendah. Tidak sampai $20 \%$ pekerja migran tersebut yang mengetahui konsep ABC (Abstinen, Be faithfull, Condom Use) sebagai perilaku pencegahan penularan HIV, walaupun sebagian besar responden pernah mendengar tentang AIDS (DinkesAceh, 2008).

Propinsi NTB termasuk urutan ke9 jumlah kasus AIDS terbanyak di 10 propinsi di Indonesia dengan jumlah kasus sebanyak 44 kasus (Kemenkes-RI, 2011). Berdasarkan data KPAD NTB (2011), dari 494 penderita HIV/AIDS tersebut jika dilihat berdasarkan status pekerjaan/profesi maka sebarannya antara lain narapidana 6 orang, swasta 131 orang, ibu rumah tangga dan balita 70 orang, pegawai negeri sipil 21 orang, TNI/POLRI 11 orang, dan pekerja migran (TKI) sebanyak 33 orang, dan sisanya (222 orang) belum teridentifikasi. (KPA-NTB, 2011).

Terkait dengan perilaku berisiko tertular HIV/AIDS, menurut Yayasan Spiritia (2009), yang dimaksud dengan perilaku berisiko tertular HIV/AIDS adalah melakukan sesuatu yang membawa risiko tinggi terkena infeksi pada dirinya atau orang lain. Kita biasanya tidak tahu siapa terinfeksi HIV dan siapa yang tidak, jadi kegiatan berikut termasuk berisiko tinggi (Spiritia, 2009) :

a. Berhubungan seks dengan memasuki vagina, dubur atau mulut tanpa memakai kondom. Laki-laki dengan HIV dapat menulari baik pasangan laki-laki maupun perempuan saat berhubungan seks melalui dubur tanpa perlindungan

b. Memakai jarum suntik dan semprit (insul), atau alat tindakan medis yang tidak steril, yang mungkin tercemar oleh darah orang lain, baik pada dirinya maupun orang lain

c. Menerima transfusi darah yang terinfeksi

Sementara itu, perasaan kesepian pada pekerja migran juga merupakan salah satu faktor bagi pekerja migran dalam melakukan hubungan seks yang berisiko. Penelitian pada pekerja migran asal Mexico di kota New York menunjukkan bahwa tingkat kesepian yang tinggi mempunyai asosiasi kuat dengan frekuensi perilaku seksual berisiko. Perasaan kesepian membuat pekerja migran berkunjung ke bar-bar atau club-dance sehingga merupakan faktor yang meningkatkan risiko hubungan seksual berisiko (Miquel Munoz-Laboy, 2009).

Berdasarkan latar belakang tersebut penulis penulis tertarik untuk mengetahui apakah ada hubungan antara perasaan kesepian dengan perilaku berisiko tertular HIV pada TKI di Kabupaten Lombok Timur.

\section{METODE PENELITIAN Rancangan Penelitian}

Penelitian ini merupakan penelitian kuantitatif dengan pendekatan crossectional analytic. Populasi pada penelitian ini adalah seluruh TKI baik laki-laki maupun perempuan (TKW) di Kabupaten Lombok Timur Propinsi NTB. Sampel pada penelitian ini berjumlah 461 responden.

\section{Variabel Penelitian}

Variabel Perasaan Kesepian (X) : Adalah perasaan sepi yang dialami oleh TKI sebagai dampak keterpisahan dengan keluarga dan lingkungan asal. 
Kuesioner menggunakan modifikasi dari UCLA Loneliness Scale yang terdiri dari 10 pertanyaan dengan option jawaban sering (skor 4), kadang-kadang (3), jarang (2), dan tidak pernah (1). Dikatagorikan menjadi :

a. Tidak kesepian (skor 10-14)

b. Kesepian normal (15-20)

c. Kesepian sedang (21-30)

d. Kesepian berat/parah (skor di atas 30)

Variabel Perilaku Berisiko Tertular HIV/AIDS (Y) : didefinisikan sebagai segala bentuk praktik/tindakan yang dilakukan oleh TKI yang berisiko terhadap penularan HIV/AIDS. Dikatagorikan menjadi :

a. Perilaku tidak berisiko adalah salah satu dari perilaku berikut ini :

1) Tidak melakukan hubungan seks samasekali (abstinen)

2) Melakukan hubungan seks tanpa penetrasi oral, anal dan vagina (misalnya : masturbasi, onani, seks paha, menyentuh atau bercumbu saja)

3) Melakukan hubungan seks dengan penetrasi oral, dan/atau anal, dan/atau vagina dengan satu pasangan seksual dengan selalu menggunakan kondom

4) Tidak mengkonsumsi narkoba suntik

b. Perilaku berisiko rendah adalah salah satu perilaku berikut ini :

1) Melakukan hubungan seks (penetrasi oral, dan/atau anal, dan/atau vagina) dengan satu pasangan tetapi tanpa kondom

2) Melakukan hubungan seksual (penetrasi oral, dan/atau anal, dan/atau vagina) dengan lebih dari satu pasangan seksual dengan selalu menggunakan kondom

c. Perilaku berisiko sedang adalah salah satu perilaku berikut ini :
1) Melakukan hubungan seksual (penetrasi oral, dan/atau anal, dan/atau vagina) lebih dari satu pasangan seksual dengan sesekali menggunakan kondom

2) Melakukan tatto, tindik, piercing tanpa jaminan sterilitas jarum yang digunakan (jarum digunakan bergantian)

d. Perilaku berisiko tinggi adalah salah satu perilaku berikut ini :

1) Melakukan hubungan seksual (penetrasi oral, dan/atau anal, dan/atau vagina) dengan lebih dari satu pasangan seksual dan tidak pernah menggunakan kondom

2) Mengkonsumsi narkoba suntik dengan pemakaian jarum suntik secara bergantian

\section{Instrument}

Instrument yang digunakan dalam penelitian ini merupakan kuesioner yang dimodifikasi dari Survey Surveilans Perilaku (SSP) tahun 2005 yang dilaksanakan oleh BPS yang bekerjasama dengan Depnakertrans dengan dukungan GFATM (BPS, 2005), SSP Remaja tahun 2010, UCLA Loneliness Scale dan beberapa sumber lainnya.

\section{Analisis Data}

Uji statistik yang digunakan untuk menguji hubungan perasaan kesepian dengan perilaku berisiko tertular HIV/AIDS pada TKI diuji dengan uji Chi Square pada tingkat kepercayaan $95 \%(\alpha=0,05)$, bila $\mathrm{p}<0,05$ maka variabel diatas dinyatakan berhubungan secara signifikan. 


\section{HASIL PENELITIAN}

Pada penelitian ini dilakukan pengumpulan data dengan kuesioner dan pedoman wawancara pada 461 responden yang tersebar di 20 kecamatan di Kabupaten Lombok Timur.

Tabel 1.1. Katagori perasaan kesepian responden TKI di Kabupaten Lombok Timur

\begin{tabular}{|l|l|r|r|}
\hline No & \multicolumn{1}{|c|}{ Katagori } & Frek & \% \\
\hline 1 & Tidak Kesepian & 31 & 6,7 \\
\hline 2 & Kesepian Normal & 111 & 24,1 \\
\hline 3 & Kesepian Sedang & 248 & 53,8 \\
\hline 4 & Kesepian Berat & 71 & 15,4 \\
\hline & Total & 461 & 100,0 \\
\hline
\end{tabular}

Tabel 1.2. Perilaku berisiko tertular HIV/AIDS pada TKI di Kabupaten Lombok Timur.

\begin{tabular}{|l|l|r|r|}
\hline No & $\begin{array}{c}\text { Perilaku berisiko } \\
\text { tertular HIV / AIDS }\end{array}$ & Jml & \% \\
\hline 1 & Tidak Berisiko & 54 & 11,7 \\
\hline 2 & Berisiko Rendah & 183 & 39,7 \\
\hline 3 & Berisiko Sedang & 40 & 8,7 \\
\hline 4 & Berisiko Tinggi & 184 & 39,9 \\
\hline & Total & $\mathbf{4 6 1}$ & $\mathbf{1 0 0 , 0}$ \\
\hline
\end{tabular}

Tabel 1.3. Hubungan Perasaan Kesepian TKI di Kabupaten Lombok Timur Dengan Perilaku Berisiko HIV/AIDS

\begin{tabular}{|l|l|r|r|r|r|r|r|}
\hline No & Kata & \multicolumn{4}{|c|}{$\begin{array}{c}\text { Perilaku Berisiko } \\
\text { gori }\end{array}$} & \multicolumn{3}{|c|}{ Tertular HIV } & $\begin{array}{r}\text { Nilai } \\
\text { Chi-Sq. }\end{array}$ \\
\cline { 2 - 6 } & & Tdk & Rdh & $\begin{array}{r}\text { Sd } \\
\text { g }\end{array}$ & $\begin{array}{r}\text { Tn } \\
\text { g }\end{array}$ & & \\
\hline 1 & $\begin{array}{l}\text { Tidak } \\
\text { Kese- } \\
\text { pian }\end{array}$ & 4 & 18 & 1 & 8 & 31 & 0,013 \\
\hline 2 & $\begin{array}{l}\text { Kese- } \\
\text { pian } \\
\text { Normal }\end{array}$ & 17 & 45 & 11 & 38 & 111 & \\
\hline 3 & $\begin{array}{l}\text { Kese- } \\
\text { pian } \\
\text { Sedang }\end{array}$ & 29 & 101 & 23 & 95 & 248 & \\
\hline 4 & $\begin{array}{l}\text { Kese- } \\
\text { pian } \\
\text { Berat }\end{array}$ & 4 & 19 & 5 & 43 & 71 & \\
\hline & Total & & & & & & \\
\hline
\end{tabular}

\section{PEMBAHASAN}

Pada penelitian ini, perilaku berisiko tertular HIV/AIDS dikatagorikan menjadi 4 (empat) yaitu tidak berisiko, risiko rendah, resiko sedang dan resiko tinggi. Pengkatagorian ini didasarkan pada patofisiologi HIV/AIDS (Nursalam, 2008) dan berdasarkan definisi perilaku berisiko tertular HIV/AIDS dari Yayasan Spiritia (2009).

Perilaku tidak berisiko apabila responden tidak pernah melakukan hubungan seksual sama sekali, melakukan hubungan seks dengan satu pasangan dan selalu menggunakan kondom, serta tidak mengkonsumsi narkoba suntik.

Perilaku berisiko rendah apabila responden melakukan hubungan seksual dengan satu pasangan seksual tanpa kondom, atau berganti-ganti pasangan dengan selalu menggunakan kondom.

Perilaku berisiko sedang adalah melakukan hubungan seks dengan lebih dari 1 pasangan seksual kadang-kadang memakai kondom, serta melakukan tattoo/piercing tanpa jaminan sterilitas alat.

Perilaku berisiko tinggi apabila responden melakukan hubungan seksual dengan lebih dari 1 pasangan seks tidak pernah menggunakan kondom, dan konsumsi narkoba suntik dengan penggunaan jarum suntik secara bergantian.

Dari hasil penelitian didapatkan bahwa presentase terbesar perilaku responden adalah perilaku berisiko tinggi (39,9\%), disusul dengan perbedaan yang tipis yaitu perilaku berisiko rendah $(39,7 \%)$, kemudian perilaku tidak berisiko $(11,7 \%)$ dan persentase yang terendah adalah perilaku berisiko sedang yaitu $(8,7 \%)$. Tingginya persentase perilaku berisiko tinggi tidak 
terlepas dari banyaknya responden yang melakukan serial monogamy dan poligami yang dimasukkan dalam katagori perilaku berisiko tinggi karena berhubungan seks lebih dari 1 pasangan seksual dan tidak pernah menggunakan kondom.

Pada penelitian ini perasaan kesepian dinilai dengan menggunakan kuesioner yang diadaptasi dari UCLA Lonelinnes Scale dengan katagori tidak kesepian, kesepian normal, kesepian sedang, dan kesepian berat. Sebagian besar responden berada pada tingkat kesepian sedang $(53,8 \%)$, disusul dengan kesepian normal $(24,1 \%)$, kesepian berat $(15,4 \%)$, dan yang paling sedikit adalah tidak kesepian (6,7\%). Dari hasil pengolahan data statistik didapatkan nilai korelasi Chi-Squared sebesar 0,013 yang berarti lebih kecil dari nilai Alfa 0,05. Dengan demikian dapat disimpulkan ada hubungan antara kesepian dengan perilaku berisiko tertular HIV/AIDS pada TKI di Kabupaten Lombok Timur. Hubungan bersifat positif yang berarti semakin tinggi tingkat perasaan kesepian, semakin tinggi pula perilaku berisiko tertular HIV/AIDS pada TKI di Kabupaten Lombok Timur.

Perasaan kesepian dianggap sebagai faktor penguat bagi terjadinya perilaku berisiko tertular HIV/AIDS. Perasaan kesepian mendorong individu untuk melakukan tindakan-tindakan yang akhirnya mengarah kepada hubungan seksual yang berisiko. Penelitian pada pekerja migran asal Mexico di kota New York menunjukkan bahwa tingkat kesepian yang tinggi mempunyai asosiasi kuat dengan frekuensi perilaku seksual berisiko (Miquel Munoz-Laboy, 2009).

\section{PENUTUP}

\section{Kesimpulan}

Perasaan kesepian berhubungan dengan perilaku berisiko HIV/AIDS. Semakin tinggi perasaan kesepian, semakin tinggi perilaku berisiko tertular HIV/AIDS.

\section{Saran}

Bagi para TKI agar lebih mengetahui dan memahami tentang HIV/AIDS serta menghindarkan diri dari perilaku berisiko HIV/AIDS, mengisi waktu lowong dengan kegiatan yang bersifat positif sehingga mengurangi perasaan kesepian yang dirasakan.

\section{DAFTAR PUSTAKA}

Arikunto, S. 2002. Prosedur Penelitian : Suatu Pendekatan Praktek. Jakarta: Rineka Cipta.

BPS. 2005. Survei Surveilans Perilaku (SSP). Badan Pusat Statistik dan Departemen Tenaga Kerja dan Transmigrasi dengan dukungan GFATM.

BPS. 2010. Hasil Survey Nasional Pola Remitansi TKI di Nusa Tenggara Barat

DinkesAceh. 2008. Laporan Survey Surveilans Perilaku Berisiko Tertular HIV di Nanggroe Aceh Darussalam. Aceh: Dinas Kesehatan Pemerintah Propinsi Nanggroe Aceh Darussalam.

Ford, K. 2007. Sexual Partners and Condom Use of Migrant Workers in Thailand. AIDS Behav., 11, 905914.

Hugo, G. 2001. Population Mobility and HIV/AIDS: UNDP South East Asia HIV \& Development Office.

Hugo, G. 2001. Population Mobility and HIV/AIDS in Indonesia. Jakarta: UNDP South East Asia HIV and 
Development Office, ILO Indonesia, UNAIDS Indonesia.

ILO. 2005. Panduan Bersama ILO/WHO tentang Pelayanan Kesehatan dan HIV/AIDS. Jakarta: Direktorat Pengawasan Kesehatan Kerja Depnakertrans RI.

Notoatmodjo, S. 2005. Metodologi Penelitian Kesehatan. Jakarta: Rineka Cipta.

Nursalam. 2008. Asuhan Keperawatan Pada Pasien Terinfeksi HIV/AIDS. Jakarta: Salemba Medika.

Purwaningsih, S. 2004. Perilaku Seks Berisiko Tinggi : Intensitas dan Insiden PMS dan HIV/AIDS. Populasi, 15.

Spiritia. 2009. Dasar AIDS. Retrieved from http : //spiritia.or.id/

Utami, D. R. W. W. 2007. Determinan Perilaku Berisiko Tertular HIVIAIDS Pada Karyawan Lakilaki di Perusahaan Besar. Magister, Universitas Indonesia, Jakarta.

Wulan, G. S. 2007. HIV/AIDS dan Migrasi : Menyambung Mata Rantai yang Putus. Bulletin Pekerja Migran dan HIV AIDS. 